\title{
Franz Kafka's The Castle: A foucauldian reading
}

\author{
Afrouz Yari $^{1}$, Shahram Afrougheh ${ }^{2}$ \\ ${ }^{1}$ M. A. of English Literature, Islamic Azad University, Boroujerd Branch, Iran \\ ${ }^{2}$ Assistant Professor of English Literature, Islamic Azad University, Boroujerd Branch, Iran
}

\section{Email address:}

yariafrouz@yahoo.com (A. Yari), shahram_afrougheh@yahoo.com (S. Afrougheh)

\section{To cite this article:}

Afrouz Yari, Shahram Afrougheh. Franz Kafka's The Castle: A Foucauldian Reading. International Journal of Literature and Arts. Vol. 1, No. 3, 2013, pp. 63-67. doi: 10.11648/j.ijla.20130103.18

\begin{abstract}
This study detects the notion of "power" in The Castle by Franz Kafka throughout the idea of Foucauldian hierarchy, oppression, power, knowledge and resistance. Kafka in this novel shows man's futile attempts to overcome the powerful impact of industrialism and its domination over man's life. The Castle is a societal network and shows the characters in action in a way that strengthens and empowers a capitalist society. In Foucauldian sense, power unconsciously produces and controls everything; it necessarily does not lead to despotism. However, this power makes awareness in the public which can be seen in Kafka's characters in this novel. In this research, the incidents taking place in The Castle will be depicted, and as a matter of fact, this study makes use of these events to magnify the abuse of power in a capitalist society. In addition, another main purpose in this research is to show how Kafka has magnified the characters institutionalized and their separation from the society. Particular focus is given to the role of Other's power that separates oppression, resistance, and hierarchy among people to promote his normalized knowledge.This paper attempts tomake a sociological study on Kafka's The Castle.
\end{abstract}

Keywords: Hierarchy, Oppression, Power, Knowledge, Resistance

\section{Introduction}

The Castle has a story centering round a character called $\mathrm{K}$. The protagonist, K., coming from outside and ignorant of the village and the castle, has painfully to learn their ways and to discover that, despite all his efforts, he cannot gain access to the castle. So far, this may seem to match the associations of gloom and oppression suggested by the term 'Kafkaesque'. Kafka, however, has much more to offer than the 'Kafkaesque', and if one can put aside such presuppositions, The Castle provides many surprising discoveries. It has a vividly presented material and social setting. We are in a remote village, in the depth of winter. The snowbound village is repeatedly evoked: 'more and more little houses, their window-panes covered by frostflowers', 'a narrow alley where the snow lay even deeper. Pulling his feet out of it as they kept sinking in again was hard work' (Robertson 13). We meet the families of the tanner Lasemann and the cobbler Brunswick, and hear about their standing in the village; and we are told at great length about the family of Barnabas, the castle messenger, and how the family are in bad odour because of their refractory attitude towards the castle. And whenever a new figure is introduced, he or she is neatly characterized, so that even those who appear briefly the carter Gerstacker, the village schoolmaster, the schoolmistress Gisa and her languishing suitor Schwarzer are vivid presences. The novel is also concerned with authority of various kinds. The castle is said to belong to Count Westwest, whom we never see. In his absence the castle is run by a huge staff of bureaucrats, arranged in a hierarchy, who manage the affairs of the village. There is much satire on bureaucratic confusion and inefficiency. But it is also clear that the bureaucrats arrogate to themselves the respect formerly paid to the vanished aristocracy. Kafka was writing just after the collapse of the Austro-Hungarian, German, and Russian empires. His novel asks in part what will take the place of traditional authority.

\section{The Castle in the Light of Michel Foucault's Theories}

This research applies an innovative approach to explore the processes Foucault's work, like Kafka's has inspired an imposing collected of analyses, but like other postmodern 
investigations, his multidimensional work is difficult to categorize because it actively a crosses disciplinary boundaries, producing dense philosophical inquiries into multiple fields such as art, economics, sociology, philosophy highlighting the complex interconnectedness of discourse and stressing the fact that the disciplines themselves are historical. The main ideas of Foucault's theories: Power/Knowledge, oppression, resistance and also can be grouped according to its four parts: power/knowledge, hierarchy, oppression, and resistance which we as a reader can find the traces of these four parts in Kafka's The Castle. Foucault wants to contrast two forms of penal systems in the western societies in The Castle, but the research he discusses in power and knowledge are relevant to every modern western society.

The first discourse present in The Castle is a power/knowledge. According to Foucault Power is then everywhere, in every relationship; we are constantly subjecting it and being objects of it. Take for example a male worker. He is obviously an object of his boss's power; but if he joins a union and goes on strike, he subjects his boss to the collective power he and his co-workers possess.

If the union bureaucracy then calls off the strike against his wishes, he is now an object of their power. Now let's say he is the sole breadwinner of a traditional family but he drinks a good portion of his wages; he has then subjected his family to his power as patriarch in a patriarchal world. So Mills says: Foucault's main argument is focused on power. Power is a relationship between individuals, in which one affects another's action. For Foucault, power is not restricted to a person or a group but as a network of relations which circulates through society; Foucault refers to "power not only in a negative sense but in a positive sense which is widespread among the whole society." (Mills: 37).Michel Foucault did believe this idea about power. He is one of the few writers on power who recognizes that power is not just a negative, coercive or repressive thing that forces us to do thing against our wishes, but can also be a necessary, productive and positive force in society.

We must cease once and for all to describe the effects of power in negative terms: 'excludes', it 'represses', 'censors' .it 'abstracts' ,It 'masks', it 'conceals' in fact power produces; it produces reality; it produces domains of objects and rituals of truth. The individual and the Knowledge that may be gained of him belong to this production'. (Foucault1991: 194).

The castle with its officials and guardians abuse their power by their superiority to the common people in the village. It is stated that the castle is a fortified garrison occupied by many mysterious devils, but the ordinary people have imagined that the castle is occupied by the divine law and the divine grace. The officers are indifferent to good and they have no idea about what love, mercy, charity and majesty are. The villagers respect the officials with fear and anxiety since they rule wildly and their insatiable appetites cannot be filled. Their behavior is full of scandals. They were even ready to kill others for their pleasure and also very majestic in their cruelty. Therefore the researcher has quoted a few lines from the novel to show the officials' misbehavior in the villagers' attitude. Kafka writes:

'No,' said Olga, 'there can be no question of sympathy or anything of the kind. Young and inexperienced as we were, we knew that, and so did our father, of course, but he have forgotten it just as he had forgotten almost everything. His plan was to stand on the road close to the castle, where the officials' carriages drive by and somehow or other present his petition for forgiveness there. To be honest, it made no sense at all, even if the impossible had happened and his plea really had come to the ear of some official. Can a single official forgive anyone? At the most, it must be a matter for the authorities as a whole, but even the authorities as a whole probably can't forgive, they can only judge". (Robertson: 189).

Therefore, according to above quoted paragraph, Power is then everywhere, in every relationship, power can exist in many forms, power is totally dependent on relationships. According to Foucault there is no relationship without a concept of power and all relations between people are power relations in which this power is not always negative.

The second discourse present in The Castle is hierarchy and normalization. The social inequalities are ever present in the society $\mathrm{K}$. visits and this lack of justice frustrates $\mathrm{K}$. in such a way that he is mixed up and cannot have a discriminating criterion to achieve the truth. K. compares his first sight of the castle with his home town that he has not been there for a long time. In the same way that the church has a tower higher than any other construction in the city, the castle's spire rose above any other structure in the village which indicated the top and superior position of that building there. The repetitious houses of the village makes them invisible in the eyes of any observer, while the castle is recognized from a distance by its lofty structure.

The superior castle seems to be the realm of order and meaning, while for the villagers the new and the old are one and the same thing. Change and progress are mere illusions in reality. In the same way that the head rules the body, the castle with the superior people working in it are standing at the top and the rest of the villagers are inferior and have to bow to the orders of their masters."The castle is standing in the village as a personified devil which is an allegory of evil for K., the protagonist. It is a castle that is like any other castle and it stands for power and authority" (Darrow 42).

$\mathrm{K}$. wants to ask for permission to enter the castle in order to start his job as a land surveyor. He states that the supreme lord of the castle, Count Westwest is expecting him. Although he is willing to start his job under any conditions and even work there as a worker, he is not allowed to enter and fulfill a certain duty there. His undertaking to enter the castle is repeatedly delayed and he becomes disappointed. As he comes to the village, his success or failure is foreshadowed by the castle which is 
covered by mists and clouds. There was a mysterious scene in which there was no light to see the gloomy castle. K. stood for a long time looking at the empty illusion above him. Furthermore, there are two assistants by the names of Arthur and Jeremiah whom K. faces them as he comes to the village. He thinks of them as snakes and these two were the ones who had already worked with K. The superiority and the false hierarchy of the castle officials can be shocking. When K. looks for Klamm to visit him, he goes to the inn that Klamm has gone to eat a meal and he is not allowed to enter that place to see him. Instead, he has to stay outside awaiting him, and there he is excited by the driver of Klamm's sledge and he wants to try one of the brandy bottles Klamm has kept there. The strong pleasant smell of the bottle was strange for him and he actually praised the taste of Klamm's drinks. The following excerpt clarifies how he feels at drinking a bottle of Klamm's brandy:

He pulled one out, unscrewed the cap, and took a sniff, he had to smile, it smelled so sweet, so caressing, as when you hear praise and fine words from someone of whom you are very fond and you are not at all sure what it is about and do not wish to know and are simply happy in the knowledge that it is the loved one speaking. 'That's brandy?' K. wondered in some doubt, and tasted it out of curiosity. Yes, it was brandy, astonishingly, it burned and it warmed. The way it changed as you drank it, from something that was little more than a source of fragrance into a drink for a sledge driver (Robertson: 74).

There is a comparison between the hierarchal castle and the legend of the doorkeeper in The Trial. In the same way that K. in The Castle cannot visit Klamm under any conditions, the same thing happens for Joseph $\mathrm{K}$. in The Trial. There, a countryman comes to the gate of the Law, as $\mathrm{K}$. comes to the village with the doorkeeper telling him that he cannot enter yet; the man spends all of his life awaiting any permission to enter the gate of law, but he is only told in his dying hour that the entrance was intended specially for him. The doorkeeper is very much like the castle official K. sees only a picture soon after he arrives in the village: both Klamm and the doorkeeper in these two novels have big beards and prominent hooked noses. Both are members of a hierarchy. The Castle has a manager with several deputy managers, officials and secretaries, and the doorkeeper in The Trial evokes a series of further doorkeepers and the countryman says: 'The sight of just the third is too much even for me.' The same thing happens in The Castle, when the landlady of the Bridge Inn asks K., 'how did you bear the sight of Klamm?' The doorkeeper states that he was very powerful, and also the landlord mentions the same thing in describing the officials.

The third discourse present in The Castle is oppression. Michel Foucault analyses the relations between the individual and the wider society without assuming that the individual is powerless in relation to institutions or to the State. He does not minimise the restrictions placed on individuals by institutions; in much of his work he is precisely focused on the way institutions act upon individuals. However, by analyzing the way that power is dispersed throughout society, Foucault enables one to see power as enacted in every interaction and hence as subject to resistance in each of those interactions. This makes power a much less stable element, since it can be challenged at any moment, and it is necessary to continuously renew and maintain power relations. Thus, his analysis of power has set in motion an entirely Therefore what is understood from the novel, specially, the above Kafka's statement is that the way in which oppression operates during winter in the village.

There are many examples showing the villagers' gratuitous misery and oppression. The first instance is about the landlady, Gardena, who speaks with K. about her life story. She states that she was abandoned by Klamm after she was abused and then she was able to find some comfort from a stable boy whose name was Hans. Gardena's father happened to see them in the stable and he leased the inn to them and they have been running the business of the inn ever since. She was ready to be Hans's wife because she was once Klamm's mistress who had made her more marriageable. They knew it a blessing to be Klamm's mistress. Another example of the villager's misery and oppression is the Barnabus family. Since Amalia had refused Sortini's rude requests, the family thinks they are cursed and this is the reason for the family's misery and poverty. The neighbors do not care about them. They beg for mercy and they spend days in the roadside to see an official passing in a carriage to get his attention, but they know that it is impossible. There are some other examples of the villagers' oppression in the novel.

The forth discourse present in The Castle is resistance. $\mathrm{K}$. is a rationalist who has come from outside and is ready fight against the superstitious customs of the villagers who blindly bow to the rulers in the village without questioning their requests. When K. says that he wants to visit Klamm, the landlady who is Klamm's former lover claims that it is not possible to see Klamm, but $\mathrm{K}$. insists that there is a way to see Klamm in the castle and he persists in the lady's helping him to get in touch with Klamm. Later on when he is employed in the village school as the janitor, he argues with the teacher and the mayor. The teacher wants to dismiss him from the school, but he claims that he has not been employed by the teacher to be sacked from the school as he states and he resists the power of the school authorities. Another instance of Klamm's resistance is that he does not accept Momus, the secretary of the castle, to question him. Finally, when he hears the rude sexual requests of Sortini to Amalia, he gets angry and wants her father to arrange an official complaint against Sortini Although there are some resisting forces in the society depicted by Kafka, there is always means of terror ever present in the village which make the villagers face a frightening atmosphere in order not to resist their power and endanger their ever present and ever powerful authority. Always the officials try to threaten and abuse the villagers 
in a variety of ways. Never anyone lives in peace. Noise comes from everywhere, from the crack of dawn up to midnight. It has been shown by Kafka in the twentieth chapter of his novel that the maids were cleaning the secretaries' rooms and also by the questions they were asked about the files which were missing. Terror was running everywhere even in the dead of the night, the chambermaids were fearful and did not know what to do with the calm tiptoeing at the back of their rooms. They had to hold themselves tightly to lessen their tensions and fearful feelings which ran at every hour. $\mathrm{K}$. is contemplated a force of sense and enlightenment in the village who are all deceived by its unreasoning reverence for tradition. K.'s business is to check and correct the people's land boundaries. He might therefore change the property relations in the village. He is required in the village and it needs to be freed from all those false reverence.

The material poverty and emotional misery are what $\mathrm{K}$. experiences in that village. $\mathrm{K}$. wants to resist the power and the false superiority of the villagers. Gerstacker, a coachman who first does not take $K$. to the castle, is physically mistreated, and $\mathrm{K}$. is obsessed by the sufferings of the oppressed in the village. It seemed that their skulls had been beaten flat. Women, especially the landladies of the inns are all exhausted by hard work. K. stands against all these wrongly mistreatment of the oppressed, but the fact is that they justify the officials' maltreatment of themselves. The villagers are passively mistreated by the authorities and they face a man, K., who for the first time tries to defend the human rights and he is the first one who simply argues what human life is about.

\section{The Comparison between The Castle and The Trial}

$\mathrm{K}$. becomes the Land Surveyor in The Castle. Again the reader is confronted with a translucent, powerful, and authoritative organization: the Castle. The resemblance of this work to The Trial is unmistakable. However, the setting and development and plot are largely different. The tone of The Castle is serious, but not sinister as in The Trial. It might seem that both works are expressing the same idea of individual via-a-via state and how misgivings in either can lead to tragic consequences, but The Castle goes further. The Land Surveyor (who is also named $K$ ) is not coerced to do anything in this work. He has been summoned to the village in which the Castle resides for some routine surveying work, or so he thinks. After arriving, he finds that in fact, he has entered a world where his premise for being there does not suffice to gain him employment. Rather than being pursued by the faceless machinery of an impersonal institution, as in The Trial, the Land Surveyor seeks to become part of this very monolith. In both novels the action of the plot is built around the give and take of the ghost-like organization with the protagonist.

In The Castle the roles are reversed the Land Surveyor seeks to scrutinize the Castle in all its manifestations: its underlings, middle managers, and higher ups, like Klamm, the official to whom he was summoned initially. All the characters in the Castle and those connected to it are subject to the Land Surveyor's unquenchable desire to know. With each character his thirst for knowledge is different. His motive is always the same: to associate himself with the Castle, primarily through the Klamm character. He is willing to use any and all to this end.

In Barnabas, the impoverished messenger, he sees a pawn, in Frieda, the servant girl and former lover of Klamm, that becomes his mistress and betrothed, he sees an opportunity to actually enter the Castle. As the novel nears its abbreviated end, the reader is struck by the developing obsession the Land Surveyor is having with reaching the Castle. As it ends, he never accomplishes his goal of meeting the official Klamm or even entering the walls of the Castle. He is left undone, and about to embark on another intrigue with a middle-aged woman that owns the beer hall where his adventure began.

In The Castle, Kafka paints the individual as a wretch longing for power. His shameless ambition, though it may not be realized, leading him to use and discard, even those, that cares for him (as Frieda did and was). He shows with the skill of a master writer, just how much one can rationalize their naked selfishness also. The similarity with The Trial is stylistic only. There is a supportive, docile woman in both, subservient characters also: the assistants in The Castle and the jailers in The Trial. The mayor in The Castle is strikingly similar to Ks' attorney in The Trial. Yet, the stories diverge in their themes. Both have surreal settings that invoke images of secret underground worlds, but present two different perspectives on the individual and his social world.

\section{Conclusion}

In conclusion, in The Castle, the protagonist does not ultimately succeed in his plan of entering the Castle. And the failure can be laid at his door for two reasons. First, he tries to fit the life of the Castle into his rationalist categories. And secondly he does not allow others to be themselves but uses them for his own purposes thus denying them any individuality which he wants for himself. These characteristic of his are pointed out to him from time to time in the novel but he refuses to amend his ways. Kafka's work, thus, embody the predicament of a singular, historical moment at the threshold of legal and disciplinary transformation, a moment that fluctuated between the archaic modalities of linguistic based discipline and modern surveillance.

\section{References}

[1] Darrow, Robert Arnold. Kierkegaard, Kafka and the Strength of the Absurd in Abraham's Sacrifice of Isaac. Maryland: Johns Hopkins University, 2005. 
[2] Foucault, Michel. Discipline and Punish: The Birth of the Prison. Harmondsworth: 1991

[3] Mills, Sara. Michel Foucault. London: Routledge, 2003.
[4] Robertson, Ritchie. The Castle.Trans. Anthea Bell. New York: Oxford University Press, 2009. 